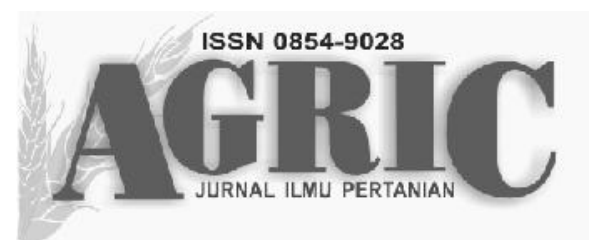

Fakultas Pertanian dan Bisnis Universitas Kristen Satya Wacana Jl. Diponegoro 52-60 SALATIGA 50711 - Telp. 0298-321212 ext 354

email: agric_fpb@yahoo.co.id, website: ejournal.uksw.edu/agric

\title{
KAJIAN MACAM LIMBAH DAN PENAMBAHAN TEPUNG TONGKOL JAGUNG TERHADAP PERTUMBUHAN DAN HASIL JAMUR TIRAM (Pleurotus ostreatus)
}

\author{
STUDIES OF VARIOUS WASTE AND CORN COB FLOUR ADDITIONS \\ TO THE GROWTH AND YIELD OF OYSTER MUSHROOM (Pleurotus ostreatus)
}

\author{
Agung Setyarini \\ Fakultas Pertanian, Universitas Veteran Bangun Nusantara Sukoharjo \\ agung.setyarini@yahoo.co.id \\ Nugraheni Retnaningsih \\ Fakultas Pertanian,Universitas Veteran Bangun Nusantara Sukoharjo \\ nretna@gmail.com
}

Diterima 3 November 2015, disetujui 21 Maret 2016

\begin{abstract}
One limiting for factor the production of oyster mushrooms was difficult to obtain the raw material of sengon wood sawdust, meanwhile, the production of oyster mushroom necessary need the nutrients in the form of bran or cornmeal. The purpose of this study was to study planting medium, the concentration of corn cob flour, and to find the effective interaction of these two factors on growth and yield of oyster mushroom. This study used a completely randomized design (CRD) with two factors, concentration of media and corn cob flour. The media used in this study are sengon sawdust, glugu sawdust, acacia wood sawdust, rice straw and bagasse, while the concentration of corn cob flour was $0 \%$ per baglog, $1 \%$ per baglog, $2 \%$ per baglog, 3\% per baglog and 4\% per baglog. Data analysis was using $F$ test level 5\% and continued with Duncan test. The results of this study showed that sawdvst sengon media generally give better effect to the growth and yield of oyster mushroom, while corn cob flour treatment concentration was not known exactly in enhancing the growth and yield of oyster mushroom. Treatment of media accelerate the deployment of mycelium old, when appearing pin head, increasing the number of fruiting bodies in a single clump and increasing the mushroom fruit body weight. Extra flour treatment corncob accelerate as emerging pin head, increasing the number of fruiting bodies in a clump and increase total body weight of mushrooms.
\end{abstract}

Keywords: Pleurotus ostreatus, Albasia falcata, Cocos nucifera, Acacia confusa, rice straw, bagasse. 


\section{PENDAHULUAN}

Jamur tiram dapat tumbuh pada media dengan nutrisi yang dibutuhkan untuk pertumbuhan dan produksinya yaitu berupa lignin, karbohidrat (selulosa dan glukosa), protein, nitrogen, serat, dan vitamin. Media tanam yang biasa digunakan dalam budidaya jamur tiram adalah serbuk gergaji kayu, sekam, dan bekatul (Shifriyah et al., 2012). Jamur tiram ini juga dapat tumbuh pada berbagai macam media yang merupakan limbah hasil pertanian, sehingga limbah pertanian ini tidak terbuang percuma dan mempunyai nilai tambah. Sebelum limbah pertanian tersebut dijadikan alternatif sebagai media tanam jamur tiram, perlu dikaji terlebih dahulu karakteristik pertumbuhan dan produksi jamur tiram yang akan dihasilkan. Untuk meningkatkan produksi jamurtiram, maka dalam campuran bahan media tumbuh selain serbuk gergaji sebagai bahan utama, perlu bahan tambahan berupa bekatul dan tepung jagung (Tjokrokusumo et al., 2008). Penambahan bekatul dalam media tumbuh jamur tiram berfungsi untuk meningkatkan nutrisi media tanam yaitu sebagai sumber karbohidrat, karbon (C), sumber nitrogen dan thiamin (Vitamin B1) berfungsi dalam pembentukan dan pengembangan tubuh buah jamur tiram putih (Suriawiria, 2006).

\section{METODE PENELITIAN}

Penelitian dilaksanakan selama 6 bulan yaitu bulan April sampai dengan September 2015. Bertempat di Kumbung Jamur "Jamur Makmur” Desa Dagen, Kecamatan Jaten, Kabupaten Karanganyar.

Bahan yang digunakan adalah serbuk gergaji kayu sengon (Albasia falcata), serbuk gergaji kayu glugu (Cocos nucifera), serbuk gergaji kayu akasia (Acacia confusa), jerami padi yang dipotong-potong, bagas/ampas tebu, air, kapur $(\mathrm{CaCO} 3)$, bekatul dan tepung tongkol jagung sebagai bahan untuk media tanam jamur (baglog). Untuk bibit jamur menggunakan bibit F3. Bahan lain yang digunakan yaitu alkohol dan gas elpiji.

Alat yang digunakan adalah kantong plastik polyetilen, kapas, cincin/ring pralon, spatula, pinset, handsprayer, lampu bunsen, laminar flow cabinet/tempat inokulasi, timbangan, ember, sekop, ayakan kawat, drum untuk sterilisasi, selang air, dan rak/kumbung pemeliharaan jamur.

Penelitian ini menggunakan Rancangan Acak Lengkap (RAL) yang disusun secara faktorial terdiri atas dua faktor perlakuan dengan tiga ulangan.

1. Faktor pertama: macam media dengan 5 taraf, yaitu:

M1: Serbuk gergaji kayu sengon +bekatul $+\mathrm{CaCO} 3$

M2: Serbuk gergaji kayu glugu + bekatul $+\mathrm{CaCO} 3$

M3: Serbuk gergaji kayu akasia + bekatul $+\mathrm{CaCO} 3$

M4: Jerami padi yang dipotong-potong + bekatul + $\mathrm{CaCO} 3$

M5: Bagas/Ampas tebu + bekatul + $\mathrm{CaCO} 3$

2. Faktor kedua: konsentrasi tepung tongkol jagung dengan 5 taraf yaitu:

J0: $0 \%$ per baglog

$\mathrm{J} 1: 1 \%$ per baglog

$\mathrm{J} 2: 2 \%$ per baglog

$\mathrm{J} 3: 3 \%$ per baglog

$\mathrm{J} 4: 4 \%$ per baglog

Data yang diperoleh dianalisis menggunakan analisis ragam dengan Uji $\mathrm{F}$ taraf 5\%, dan dilanjutkan dengan Uji Duncan taraf 5\%.

\section{HASIL DAN PEMBAHASAN}

Pengamatan meliputi lama penyebaran miselium, saat muncul pin head, jumlah total tubuh buah pada satu rumpun, berat total tubuh buah jamur. 
Lama penyebaran miselium diamati sejak munculnya miselium sampai miselium tersebut memenuhi baglog jamur. Apabila baglog tidak ditumbuhi oleh miselium maka inokulasi bibit jamur dinyatakan gagal.

Lama penyebaran miselium dipengaruhi oleh suhu, kelembaban tempat inkubasi, dan kualitas bibit jamur. Suhu yang dikehendaki berkisar 25-28p C dan kelembaban udara sekitar 80-90\%. Lama proses inkubasi berkisar antara 4-5 minggu setelah inokulasi (Achmad et al., 2013).

Dari tabel 1 menunjukkan bahwa perlakuan yang memberikan pengaruh paling cepat dalam merangsang penyebaran miselium adalah kombinasi perlakuan media sengon dengan penambahan tepung tongkol jagung $4 \%$ yaitu dengan rata-rata 32 hari dan ini tidak berbeda nyata dengan perlakuan kombinasi media sengon dengan penambahan tepung tongkol jagung $0 \%, 2 \%$ dan $3 \%$.
Media sengon tidak mengandung getah yang dapat menghambat pertumbuhan miselium. Media sengon juga mengandung nutrisi yang cukup untuk merangsang pertumbuhan miselium karena mengandung lignin, selulose dan hemi-selulose, yang ditambah dengan bekatul yang mengandung kalium yang berfungsi sebagai sebagai pembentuk protein serta pati, sehingga mempercepat pertumbuhan miselium. Kandungan vitamin B dalam bekatul akan mempercepat pertumbuhan miselium.

Perlakuan yang memberikan pengaruh paling lama dalam penyebaran miselium adalah kombinasi perlakuan media glugu dengan penambahan tepung tongkol jagung $1 \%$ yaitu rata-rata 49 hari setelah inokulasi.

Hal ini disebabkan karena kayu glugu merupakan kayu yang mempunyai tekstur keras. Sesuai dengan penelitian Kartika et al., (1995), menyatakan bahwa laju pertumbuhan miselium pada media campuran kompos serbuk gergaji

Tabel 1 Pengaruh Perlakuan Terhadap Pertumbuhan dan Hasil Jamur Tiram

\begin{tabular}{|c|c|c|c|c|}
\hline Perlakuan & LamaPenyebaran & $\begin{array}{l}\text { Saat Muncul Pin } \\
\text { Head (hari) }\end{array}$ & $\begin{array}{c}\text { JumlahTotal } \\
\text { Tubuh Buah }\end{array}$ & $\begin{array}{l}\text { Berat Total Tubuh } \\
\text { Buah Jamur (gram) }\end{array}$ \\
\hline M1J0 & $33^{\mathrm{ab}}$ & $25.33^{\mathrm{a}}$ & $47,33^{\mathrm{ij}}$ & $289,62^{\mathrm{e}}$ \\
\hline M1J1 & $34,33^{\mathrm{bc}}$ & $28^{\mathrm{b}}$ & $44,33^{\mathrm{ghi}}$ & $311,19^{\mathrm{ef}}$ \\
\hline $\mathrm{M} 1 \mathrm{~J} 2$ & $33,67^{\mathrm{abc}}$ & $27,67^{\mathrm{b}}$ & $46,00^{\mathrm{hij}}$ & $294,87^{\mathrm{e}}$ \\
\hline M1J3 & $32,67^{\mathrm{ab}}$ & $25^{\mathrm{a}}$ & $34,33^{f}$ & $266,57^{\mathrm{e}}$ \\
\hline M1J4 & $32^{\mathrm{a}}$ & $25,33^{\mathrm{a}}$ & $41,67^{\text {ghi }}$ & $311,39^{\mathrm{ef}}$ \\
\hline M2J0 & $47^{\mathrm{k}}$ & $48,67^{\mathrm{j}}$ & $21,00^{\mathrm{ab}}$ & $98,30^{\text {abcd }}$ \\
\hline M2J1 & $49^{1}$ & $48,67^{\mathrm{j}}$ & $23,67^{\mathrm{abc}}$ & $81,14^{\mathrm{ab}}$ \\
\hline $\mathrm{M} 2 \mathrm{~J} 2$ & $47,67^{\mathrm{kl}}$ & $54,33^{\mathrm{k}}$ & $30,33^{\text {def }}$ & $162,66^{\mathrm{d}}$ \\
\hline $\mathrm{M} 2 \mathrm{~J} 3$ & $44,33^{\mathrm{j}}$ & $57,33^{1}$ & $22,33^{\mathrm{abc}}$ & $78,89^{\mathrm{ab}}$ \\
\hline M2J4 & $47^{\mathrm{k}}$ & $54,33^{\mathrm{k}}$ & $25,67^{\text {bcd }}$ & $138,18^{\mathrm{bcd}}$ \\
\hline M3J0 & $39,67^{\text {gh }}$ & $44,33^{\mathrm{i}}$ & $29,33^{\text {def }}$ & $164,30^{\mathrm{d}}$ \\
\hline M3J1 & $42,33^{i}$ & $44,33^{\mathrm{hi}}$ & $25,67^{\mathrm{bcd}}$ & $159,24^{\mathrm{d}}$ \\
\hline M3J2 & $40,33^{\mathrm{h}}$ & $42,67^{\mathrm{h}}$ & $22,67^{\mathrm{abc}}$ & $117,23^{\mathrm{abcd}}$ \\
\hline M3J3 & $44,33^{\mathrm{j}}$ & $41,33^{\mathrm{g}}$ & $20,00^{\mathrm{a}}$ & $72,31^{\mathrm{ab}}$ \\
\hline M3J4 & $42,33^{\mathrm{i}}$ & $41^{\mathrm{g}}$ & $27,33^{\text {cde }}$ & $123,93^{\mathrm{abcd}}$ \\
\hline M4J0 & $40^{\text {gh }}$ & $31^{\mathrm{cd}}$ & $32,33^{\text {ef }}$ & $132,94^{\mathrm{abcd}}$ \\
\hline M4J1 & $35,33^{\mathrm{cd}}$ & $30,33^{\mathrm{cd}}$ & $23,00^{\mathrm{abc}}$ & $88,94^{\mathrm{abc}}$ \\
\hline $\mathrm{M} 4 \mathrm{~J} 2$ & $38,33^{\text {efg }}$ & $28,67^{\mathrm{b}}$ & $19,33^{\mathrm{a}}$ & $64,98^{\mathrm{a}}$ \\
\hline $\mathrm{M} 4 \mathrm{~J} 3$ & $37,67^{\text {ef }}$ & $28,33^{\mathrm{b}}$ & $34,00^{f}$ & $154,19^{\mathrm{cd}}$ \\
\hline M4J4 & $39^{\text {fgh }}$ & $32,33^{\mathrm{e}}$ & $26,67^{\mathrm{cd}}$ & $104,14^{\mathrm{abcd}}$ \\
\hline M5J0 & $36,67^{\mathrm{de}}$ & $30,67^{\mathrm{cd}}$ & $41,00^{\mathrm{gh}}$ & 248,71 \\
\hline M5J1 & $34^{\mathrm{bc}}$ & $31,33^{\mathrm{de}}$ & $40,00^{\mathrm{g}}$ & $289,72^{\mathrm{e}}$ \\
\hline M5J2 & $34,33^{b c}$ & $32,33^{\mathrm{e}}$ & $33,67^{\mathrm{f}}$ & $157,46^{\mathrm{d}}$ \\
\hline M5J3 & $34,33^{b c}$ & $33,67^{\mathrm{f}}$ & $44,33^{\text {ghi }}$ & $277,42^{\mathrm{e}}$ \\
\hline M5J4 & $37,67^{\text {ef }}$ & $30^{\mathrm{c}}$ & $50,00^{\mathrm{j}}$ & $365,1^{\mathrm{f}}$ \\
\hline
\end{tabular}

Keterangan: angka yang diikuti dengan huruf yang sama menunjukkan berbeda tidak nyata pada uji Duncan taraf 5\% 
kayu sengon dan kompos tongkol jagung lebih cepat daripada media tunggal (sengon saja atau tongkol jagung saja). Media campuran tersebut menghasilkan tekstur yang lebih baik sehingga miselium lebih mudah masuk di antara partikelpartikel substrat media dan menyerap nutrisi dari hasil pengomposan campuran media tersebut.

Glugu dan akasia merupakan jenis kayu yang mempunyai tekstur keras. Kayu yang bertekstur keras dapat digunakan sebagai media tumbuh jamur, namun harus melalui proses fermentasi yang bertujuan agar media tersebut mudah lapuk (Djarijah, 2001).

Menurut penelitian Steviani (2011), menyatakan bahwa media dari serbuk gergaji kayu sengon lebih banyak mengandung nutrisi dibandingkan dengan media dari serbuk gergaji kayu glugu dan kayu akasia, karena kayu sengon mempunyai serat yang kasar, mudah lapuk dan mempunyai kandungan nutrisi yang tinggi sehingga baik untuk pertumbuhan jamur tiram. Semakin besar komposisi serbuk gergaji kayu sengon yang diberikan maka kandungan selulosa, hemiselulosa, dan lignin juga akan meningkat. Kandungan selulosa dan lignin yang tinggi dengan nutrisi yang cukup, baik untuk mendukung pertumbuhan miselium jamur (Gramss, 1979; Kaul et al., 1981; Gujral et al.,1989 dalam Hariadi, 2013). Media serbuk gergaji kayu akasia selain mempunyai tekstur yang keras juga mengandung allelopati seperti fenol, alkaloid tertentu, asam lemak yang dapat menghambat pertumbuhan jamur tiram.

Pada variabel saat muncul pin head jerami padi belum terdekomposisi dengan baik dan muncul jamur lain pada media jerami. Hal ini sesuai dengan pernyataan Widyastanto (2012) dalam Hariadi (2013), komposisi baglog menggunakan konsentrasi nutrisi yang tinggi, sedangkan suhu dalam ruangan inkubasi panas dan pengap karena cuaca panas. Hal tersebut akan memicu munculnya bakteri termofilik dan jamur lain yang aktif bekerja pada suhu tinggi dan didukung dengan nutrisi tinggi pada baglog. Proses perombakan bahan-bahan organik itu akan memunculkan organisme-organisme lain seperti jamur-jamur liar. Kombinasi perlakuan media sengon dan pada variabel berat total tubuh buah penambahan tepung tongkol jagung $3 \%$ berdasarkan tabel 1 diketahui bahwa menunjukkan waktu paling cepat dengan ratarata 25 hari, dan tidak berbeda nyata dengan kombinasi perlakuan media sengon dengan tanpa penambahan tepung tongkol jagung dan kombinasi perlakuan media sengon dengan penambahan tepung tongkol jagung $4 \%$. Serbuk gergaji kayu sengon mengandung selulosa 49,40\%, hemiselulosa 24,59\%; lignin 26,8\% per berat kering (Marta-wijaya et al., 1989 dalam Hariadi, 2013). Kandungan selulosa dan lignin yang tinggi dengan nutrisi yang cukup, baik untuk mendukung pertumbuhan jamur.

Saat muncul pin head dengan waktu paling lama terdapat pada perlakuan kombinasi media glugu dengan penambahan tepung tongkol jagung 3\% dengan rata-rata 57,33 hari setelah pembukaaan kapas pada baglog.

Pada variabel jumlah total tubuh buah berdasarkan tabel 1 menunjukkan bahwa kombinasi perlakuan macam media dan penambahan tepung tongkol jagung yang paling banyak merangsang pertumbuhan jumlah total tubuh buah yaitu perlakuan media bagas tebu dan penambahan tepung tongkol jagung $4 \%$ dengan rata-rata 50 dan tidak berbeda nyata dengan media sengon dan tanpa penambahan tepung tongkol jagung, media sengon dan penambahan tepung tongkol jagung $2 \%$.

Perlakuan yang paling sedikit dalampembentukan jumlah total tubuh buah terdapat pada kombinasi 
perlakuan jerami padi dan penambahan tepung tongkol jagung $2 \%$. Hal ini disebabkan karena jerami yang digunakan dalam penelitian ini jerami setelah panen jadi belum terlalu kering, sehingga kombinasi perlakuan macam media dan penambahan tepung tongkol jagung yang memberikan pengaruh yang baik dalam merangsang berat total tubuh buah jamur yaitu perlakuan media bagas tebu dan penambahan tepung tongkol jagung $4 \%$ dengan rata-rata 365,1 gram, tidak berbeda nyata dengan perlakuan media sengon dengan penambahan tepung tongkol jagung $4 \%$ dan media sengon dengan penambahan tepung tongkol jagung $1 \%$.

Media bagas tebu mempunyai kandungan serat kasar mengandung $82 \%$ dinding sel yang terdiri atas : selulosa $40 \%$, hemiselulosa $29 \%$, lignin $13 \%$, dan silika $2 \%$.

Nutrisi ini sangat diperlukan untuk pertumbuhan jamur tiram (Islami et al.,2013). Semakin banyak nutrisi yang tersedia dalam media tanam maka akan menghasilkan tubuh buah jamur yang lebih besar. Protein dalam tongkol jagung dan bekatul membangun enzim dan asam amino sehingga jamur tiram putih menjadi subur

Kombinasi perlakuan yang memberikan pengaruh kurang baik yaitu media jerami dan penambahan tepung tongkol jagung $2 \%$ dengan rata-rata 64,98 gram. Hal ini disebabkan karena media jerami belum lapuk atau belum terdekomposisi dengan baik, walaupun diberi tambahan nutrisi tepung tongkol jagung tidak berpengaruh terhadap berat tubuh buah jamur.

Berat tubuh buah jamur pada setiap panen menunjukkan perlakuan media sengon atau media bagas tebu lebih baik jika dibandingkan dengan media glugu,akasia, dan jerami padi. Hal ini disebabkan karena kayu sengon mempunyai serat yang kasar, mudah lapuk dan mempunyai nutrisi yang tinggi sehingga baik untuk digunakan sebagai media tumbuh jamur tiram (Suriawira, 2000 dalam Steviani, 2013).

\section{KESIMPULAN}

Perlakuan macam media mempercepat lama penyebaran miselium,saat muncul pin head, meningkatkan jumlah tubuh buah pada satu rumpun, meningkatkan berat tubuh buah jamur. Perlakuan penambahan tepung tongkol jagung mempercepat saat muncul pin head, meningkatkan jumlah tubuh buah pada satu rumpun dan meningkatkan berat total tubuh jamur. Baglog dari media sengon secara umum memberikan pengaruh lebih baik bagi pertumbuhan jamur tiram. Perlakuan konsentrasi tepung tongkol jagung tidak diketahui secara pasti dalam meningkatkan pertumbuhan dan hasil jamur tiram.

\section{DAFTAR PUSTAKA}

Achmad, Mugiono, Tias Arlianti, Chotimatul Azmi. 2013. Panduan Lengkap Jamur. Penebar Swadaya. Jakarta.

Djarijah, N.M., A.S. Djarijah. 2001. Budidaya Jamur Tiram: Pembibitan, Pemeliharaan dan Pengendalian Hama Penyakit. Kanisius. Yogyakarta.

Hariadi. 2013. Studi Pertumbuhan dan Hasil Produksi Jamur Tiram Putih (Pleurotus ostreatus) Pada Media Tumbuh Jerami Padi dan Serbuk Gergaji. Jurnal Produksi Tanaman 1(1): 47-53.

Islami, A., Adi Setyo Purnomo., Sukesi. 2013. Pengaruh Komposisi Ampas tebu dan Kayu Sengon Sebagai Media Pertumbuhan Terhadap Nutrisi Jamur Tiram. Jurnal Sains dan Seni POMITS 2 (1): $2337-3520$.

Kartika, L., Yustina Pudyastuti dan Agustin Wydia Gunawan. 1995. Campuran Serbuk Gergaji Kayu Sengon dan 
Tongkol Jagung Sebagai Media tumbuh jamur tiram (Suriawira, 2000 dalam Steviani, 2013). Untuk Budidaya Jamur Tiram Putih. Hayati 2(1): 23-27.

Shifriyah, A., Kaswan Badami, dan Sinar Suryawati. 2012. Pertumbuhan dan Produksi Jamur Tiram Putih (Pleurotus ostreatus) Pada Penambahan Dua Sumber Nutrisi. Agrovigor 5(1): 8-13.
Steviani, S., 2011. Pengaruh Penambahan Molase Dalam Berbagai Media Pada Jamur Tiram Putih (Pleurotus ostreatus). Skripsi Fakultas Pertanian UNS. Surakarta.

Suriawiria. 2006. Budidaya Jamur Tiram. Kanisius. Yogyakarta.

Tjokrokusumo, D., Nety Widyastuti. 2008. Aspek Lingkungan Sebagai Faktor Penentu Keberhasilan Budidaya Jamur Tiram (Pleurotus sp). Jurnal Tek. Ling 9 (3): 287-293. 